\title{
Small intestinal mucosal cells in piglets fed with probiotic and zinc: a qualitative and quantitative microanatomical study
}

\author{
A. Kalita'10, M. Talukdar², K. Sarma², P.C. Kalita1, P. Roychoudhury³, \\ G. Kalita ${ }^{4}$, O.P. Choudhary ${ }^{1}{ }^{1}$, J.K. Chaudhary ${ }^{5}$, P.J. Doley' ${ }^{1}$, S. Debroy ${ }^{1}$ \\ ${ }^{1}$ Department of Veterinary Anatomy and Histology, College of Veterinary Sciences and Animal Husbandry, \\ Central Agricultural University (I), Selesih, Mizoram, India \\ ${ }^{2}$ Department of Veterinary Anatomy and Histology, College of Veterinary Science, Assam Agricultural University, \\ Khanapara, Assam, India \\ ${ }^{3}$ Department of Veterinary Microbiology, College of Veterinary Sciences and Animal Husbandry, \\ Central Agricultural University (I), Selesih, Mizoram, India \\ ${ }^{4}$ Department of Livestock Production and Management, College of Veterinary Sciences and Animal Husbandry, \\ Central Agricultural University (I), Selesih, Mizoram, India \\ ${ }^{5}$ Department of Animal Genetics and Breeding, College of Veterinary Sciences and Animal Husbandry, \\ Central Agricultural University (I), Selesih, Mizoram, India
}

[Received: 8 July 2020; Accepted: 25 July 2020; Early publication date: 7 August 2020]

Background: Probiotics and zinc are commonly used and beneficial in pig production. This work aimed to assess the effects of probiotic and zinc on the mucosal cells of the small intestine in respect to digestive capacity and immunity in pre- and post-weaned piglets.

Materials and methods: Eighteen Large White Yorkshire piglets were divided equally into control and treatment groups. The piglets were maintained in standard management conditions and were weaned at 28 days of age. The treatment group of piglets fed a mixture of probiotics orally at $1.25 \times 10^{9}$ CFU/day and zinc at $2000 \mathrm{ppm} /$ day from birth to 10 days of age. At three different age-groups viz. day 20 (pre-weaning) and, day 30 and day 60 (post-weaning), the animals were sacrificed. For histomorphology, the tissue samples were processed and stained with Mayer's haematoxylin and eosin for routine study, combined periodic acid-Schiff-Alcian blue for mucopolysaccharides and Masson-Hamperl argentaffin technique for argentaffin cells. The stained slides were observed under the microscope. The samples were processed as per the standard procedure for scanning and transmission electron microscopy. The statistical analysis of the data using the appropriate statistical tests was also conducted.

Results: The mucosal epithelium of villi and crypts were lined by enterocytes, goblet cells, argentaffin cells, microfold (M-cell) cells, tuft cells and intraepithelial lymphocytes. The multipotent stem cells were located at the crypt base. The length of the enterocyte microvilli was significantly longer $(p<0.05)$ in the treatment group of piglets. The number of different types of goblet cells and argentaffin cells was more in treated piglets irrespective of segments of intestine and age. The intraepithelial lymphocytes were located in apical, nuclear and basal positions in the lining epithelium of both villus tip and base with their significant increase

Address for correspondence: Dr. A. Kalita, Department of Veterinary Anatomy and Histology, College of Veterinary Sciences and Animal Husbandry, Central Agricultural University (I), Selesih, Aizawl-796015, Mizoram, India, tel: +91 7002560035, e-mail: arup.kalita@gmail.com

This article is available in open access under Creative Common Attribution-Non-Commercial-No Derivatives 4.0 International (CC BY-NC-ND 4.0) license, allowing to download articles and share them with others as long as they credit the authors and the publisher, but without permission to change them in any way or use them commercially. 


\begin{abstract}
in the treatment group of piglets. The transmission electron microscopy revealed the frequent occurrence of tuft cells in the lining mucosa of the small intestine in treated piglets.

Conclusions: Dietary supplementation of probiotic and zinc induced the number of different mucosal cells of villi and crypts in the small intestine that might suggest the greater absorptive capacity of nutrients and effective immunity in critical pre and post-weaned piglets. (Folia Morphol 2021; 80, 3: 605-617)
\end{abstract}

Key words: probiotic, zinc, lining cells, small intestine, piglets

\section{INTRODUCTION}

Piglets during the suckling period, exposed to a variety of stresses. Weaning stress in piglets is the major cause for economic loss to pig farmers [52]. The weaned piglets have limited digestive capacity that might trigger fermentation of undigested protein by opportunistic pathogens residing in the gastrointestinal tract results in diarrhoea [20,30]. In pig production, diarrhoea has been one of the most frequently encountered clinical signs of disease in neonatal pigs [1]. Enteric diseases in newborn piglets are estimated to account for $5-24 \%$ of the overall pre-weaning mortality [51]. The economic impact of such high death rates is huge. The immunology of the porcine intestinal tract is important to resist the piglets from disease, which may lead to retarded growth and death.

There has been considerable interest in using some probiotic microorganisms and antioxidants in feeds. Probiotics are viable microorganisms and supportive substances that, once ingested by animals, produce beneficial physiology effects by assisting in the establishment of an intestinal population, which is beneficial to the host entity and antagonistic to harmful bacteria.

Zinc is an important trace element that is naturally present in the feed and involved in various physiological functions. Feeding supplemental zinc in the form of zinc oxide to nursery pigs has decreased the incidence of nonspecific post-weaning diarrhoea [40]. Zinc is virtually present in all body tissues, but only a small amount is stored in the body. Zinc can immediately be mobilised if the intake of the element is reduced or too low. Therefore, daily consumption of sufficient zinc is necessary, as the body can only compensate for a minimal extent by the use of internal zinc pools for even a short temporary deficiency [6].

There is a paucity of available literature regarding the effects of probiotic and zinc in the cellular struc- ture of intestinal epithelium in pre and post-weaned piglets. Therefore, the present study was undertaken to evaluate and compare the combined effects of probiotic and zinc on different mucosal cells of villi and crypts of the small intestine in the control and treatment group of piglets that are responsible for digestive capacity and immunity in critical pre and post-weaned periods.

\section{MATERIALS AND METHODS}

\section{Animals}

Eighteen healthy Large White Yorkshire (LWY) piglets, irrespective of sex obtained from three sows, were utilised for the study. Care and management of the animals were provided in Instructional Pig Farm, College of Veterinary Sciences and Animal Husbandry, Central Agricultural University (I), Selesih, Aizawl, Mizoram, India. The Institutional Animal Ethics Committee (IAEC) ethically approved the animals used for the experiment vide Approval No. 770/ac/CPCSEA/ /FVSC/AAU/IAEC/17-18/490 dated 09.08.2017.

\section{Selection, dose and period of treatment}

A mixture of probiotic consisted of Lactobacillus acidophilus (650 million), Lactobacillus rhamnosus (400 million) and Bifidobacterium longum (200 million) was orally administered to the treatment group of piglets at $1.25 \times 10^{9} \mathrm{CFU} /$ day from birth to 10 days of age [35]. The zinc oxide was given orally to the treatment group of piglets at $2000 \mathrm{ppm} /$ day from birth to 10 days of age [8]. The piglets of the control group were given the same volume of sterilised saline solution.

\section{Experimental design}

Each of 6 numbers of piglets was selected from 3 sows at different stages of development as age-group of 20, 30 and 60 days. Out of the 6 piglets, 3 piglets from each litter were used as the control group (C) with basal diet and the other 3 piglets 
were fed orally with combined probiotic and zinc supplement along with the basal diet and used as treatment group ( $\mathrm{T}$ ). The basal diet used in this experiment was in pellet form and was formulated to provide the nutrient requirements [38]. The piglets were weaned at 28 days of age.

\section{Sample preparation}

The experimental animals were first anesthetised using diazepam at $2 \mathrm{mg} / \mathrm{kg}$ body weight followed by ketamine at $10 \mathrm{mg} / \mathrm{kg}$ body weight intravenously and then exsanguinated the animals. The animals were sacrificed at day 20,30 and 60 from both the groups. After sacrifice, the abdominal cavity of the animal was opened and parts of the small intestine were observed [24]. Tissue samples were taken immediately after sacrifice from the duodenum $(5 \mathrm{~cm}$ caudal to the pylorus), jejunum (In the middle of the jejunum) and ileum ( $5 \mathrm{~cm}$ cranial to the ileocaecal valve).

\section{Preparation for light microscopic examination}

For histomorphology, the tissue samples $(0.5 \mathrm{~cm})$ from each location were fixed in $10 \%$ neutral buffered formalin for 24 to 48 hours. All the tissues were dehydrated, cleared and embedded in paraffin wax as per Luna [36]. The paraffin blocks were sectioned at $5 \mu \mathrm{m}$ thicknesses, dried in room temperature overnight and stained with Mayer's haematoxylin and eosin for routine study [36], combined periodic acid-Schiff-Alcian blue (PAS-AB) for mucopolysaccharides [37] and Masson-Hamperl argentaffin technique for argentaffin cells [47]. The stained slides were visualised in Olympus BX 51 microscope and the images were captured with a ProgRes C5 Cool CCD camera.

\section{Preparation for electron microscopic examination}

For transmission electron microscopy (TEM) and scanning electron microscopy (SEM), the tissue samples were cut into small pieces of 1-2 $\mathrm{mm}$ size and were fixed in Karnovsky's fixative (2.5\% glutaraldehyde in $0.1 \mathrm{M}$ sodium cacodylate buffer at $\mathrm{pH} 7.2$ ) for 4 hours at $4^{\circ} \mathrm{C}$. After washing in $0.1 \mathrm{M}$ buffer ( 3 changes of $15 \mathrm{~min}$ each), the samples were fixed in $0.2 \mathrm{M}$ sodium cacodylate buffer till further use. The processing of samples for SEM was done as per Skrzypek et al. [48]. The viewing of the samples was carried out with a Zeiss SEM operated at $20 \mathrm{kV}$ at the Institute of Advanced Study in Science and Technology (IASST), Guwahati, Assam. The processing of samples for TEM was done at the Sophisticated
Analytical Instrument Facility (SAIF), North-Eastern Hill University (NEHU), Shillong as per the standard method [39]. The semi-thin sections were cut with an ultramicrotome at $400 \mathrm{~nm}$ thicknesses and stained with toluidine blue before making the ultra-thin sections. Ultra-thin sections were made at $50 \mathrm{~nm}$ thicknesses with an ultramicrotome, mounted on copper grids and contrasted with uranyl acetate and lead citrate. The viewing of the sections was carried out with Joel (JEM-2100) TEM operated at $120 \mathrm{kV}$ at SAIF, NEHU, Shillong, Meghalaya.

\section{Statistical analysis}

The data obtained were analysed using statistical package SPSS version 20. General Linear Model of two way ANOVA based on Fisher's least significant difference method was used to determine the significant difference among days (20, 30 and 60 days) for control and treatment groups. The significant values in the ANOVA were further tested through the Duncan multiple range test. The obtained results were presented as mean \pm SEM and differences were considered significant when $p<0.05$. An independent sample t-test has been applied between groups (control and treatment) on different days to see the significant changes.

\section{RESULTS}

The mucosal epithelium of villi and crypts of the small intestine was covered by lining cells consisting of enterocytes, goblet cells, enteroendocrine (argentaffin) cells, microfold (M-cell) cells, tuft cells and intraepithelial lymphocytes (IEL). In addition, multipotent stem cells were located at the crypt base irrespective of the group of piglets and age.

The enterocytes were simple columnar cells with basally located nuclei in villi (Fig. 1A) and crypts (Fig. 1B). The enterocyte microvilli were significantly higher $(p<0.05)$ in the treated piglets (Fig. 1C) than the control animals (Fig. 1D) in jejunum and ileum at day 30 and day 60 . An abundance of mitochondria, Golgi bodies, rough endoplasmic reticulum (ER), and lysosomes were observed in the enterocyte cytoplasm in treated piglets (Fig. 1E) than the control group of animals (Fig. 1F).

The goblet cells were located in the epithelial layer of villi (Fig. 2A) and crypts (Fig. 2B). The apical portion was distended by abundant mucus laden granules (Fig. 2C) and the basal portion shaped like a stem (Fig. 2D). Numerous rough endoplasmic reticulum, 

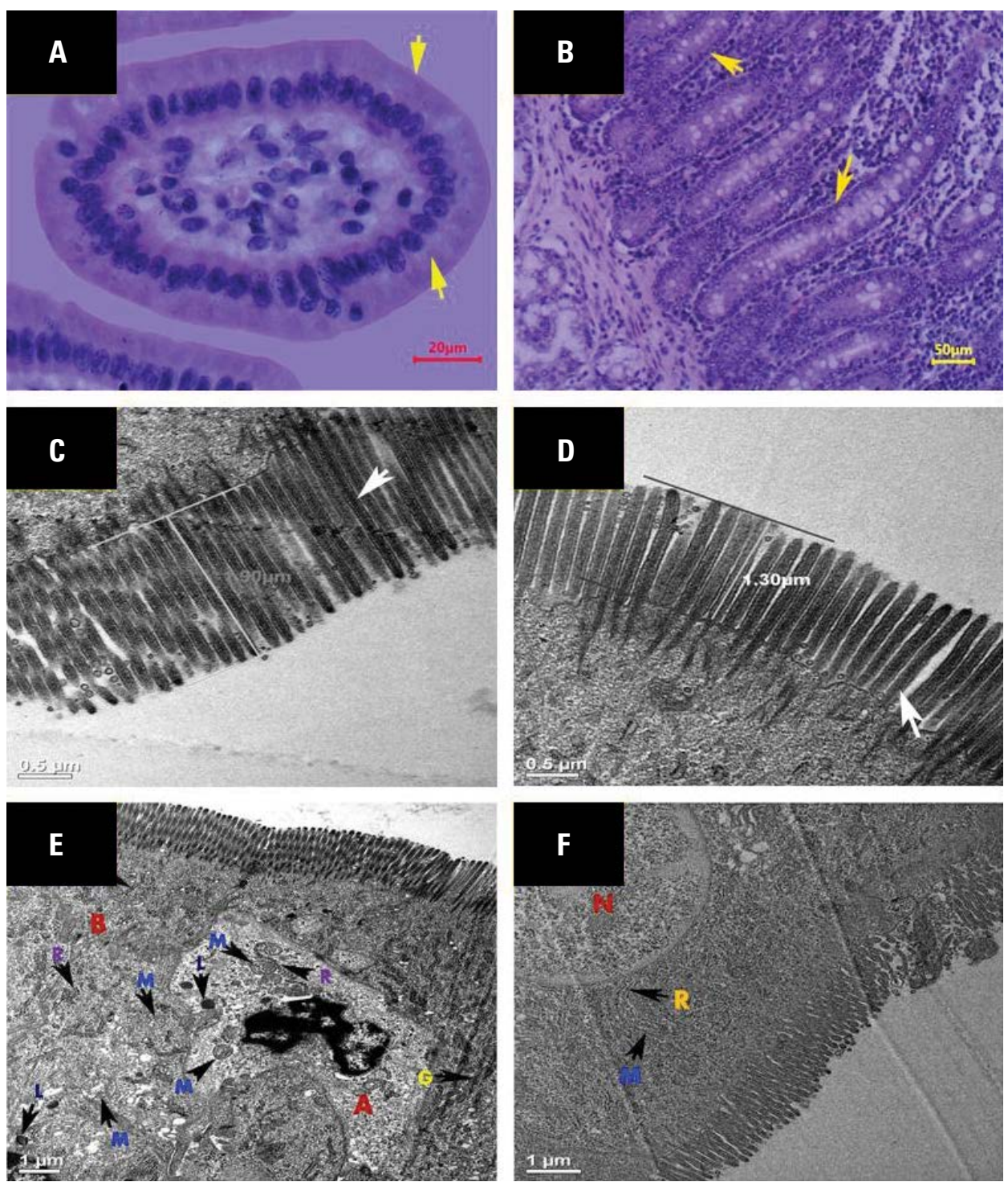

Figure 1. Enterocytes. A. Photomicrograph showing basally located nuclei (arrow) in duodenal villi of 20 days old treated piglet $\left(H \& E_{1} \times 400\right)$; B. Photomicrograph showing basally located nuclei (arrow) in jejunal crypts of 60 days old treated piglet $(H \& E, \times 100)$; C. Transmission electron microscopy (TEM) micrograph showing longer microvilli (arrow) in the jejunum of 60 days old treated piglet; $\mathbf{D}$. TEM micrograph showing shorter microvilli (arrow) in the jejunum of 60 days old control piglet; E. TEM micrograph showing macrophage (A) and enterocyte (B) with an abundance of mitochondria (M), rough endoplasmic reticulum (R), lysosomes (L) and Golgi bodies (G) in the jejunum of 60 days old treated piglet; F. TEM micrograph showing nucleus (N) and inadequacy of mitochondria (M) and rough endoplasmic reticulum (R) in the jejunum of 60 days old control piglet.

mitochondria and secretory vesicles were recorded in the goblet cells of treated piglets (Fig. 2E). PAS-AB sequential staining showed neutral, acidic and mixed neutral-acidic mucin goblet cells (Fig. 2F), irrespective of group and age. In most segments of the small intestine in treated piglets, the mixed, neutral and acidic mucin goblet cells were significantly higher both in the villi and crypts at different age-groups than the control group of animals (Table 1).

The argentaffin cells were scattered singly in villi (Fig. 3A) and crypts (Fig. 3B) among other cells within the lining epithelium. Their populations were more in the crypts than villi (Fig. $3 \mathrm{C}$ ) in both the groups of all ages. They had a narrow apex, wide base and contained many small, spheroidal, electron-dense granules (Fig. 3D). In duodenum at day 60, the number of argentaffin cells was significantly higher in villi $(p<0.05)$ and crypts $(p<0.01)$ in the treatment group of piglets (Table 2 ).

The M-cells were mostly found in the follicle associated epithelium of Peyer's patches in jejunum and ileum. They had less developed brush border with 

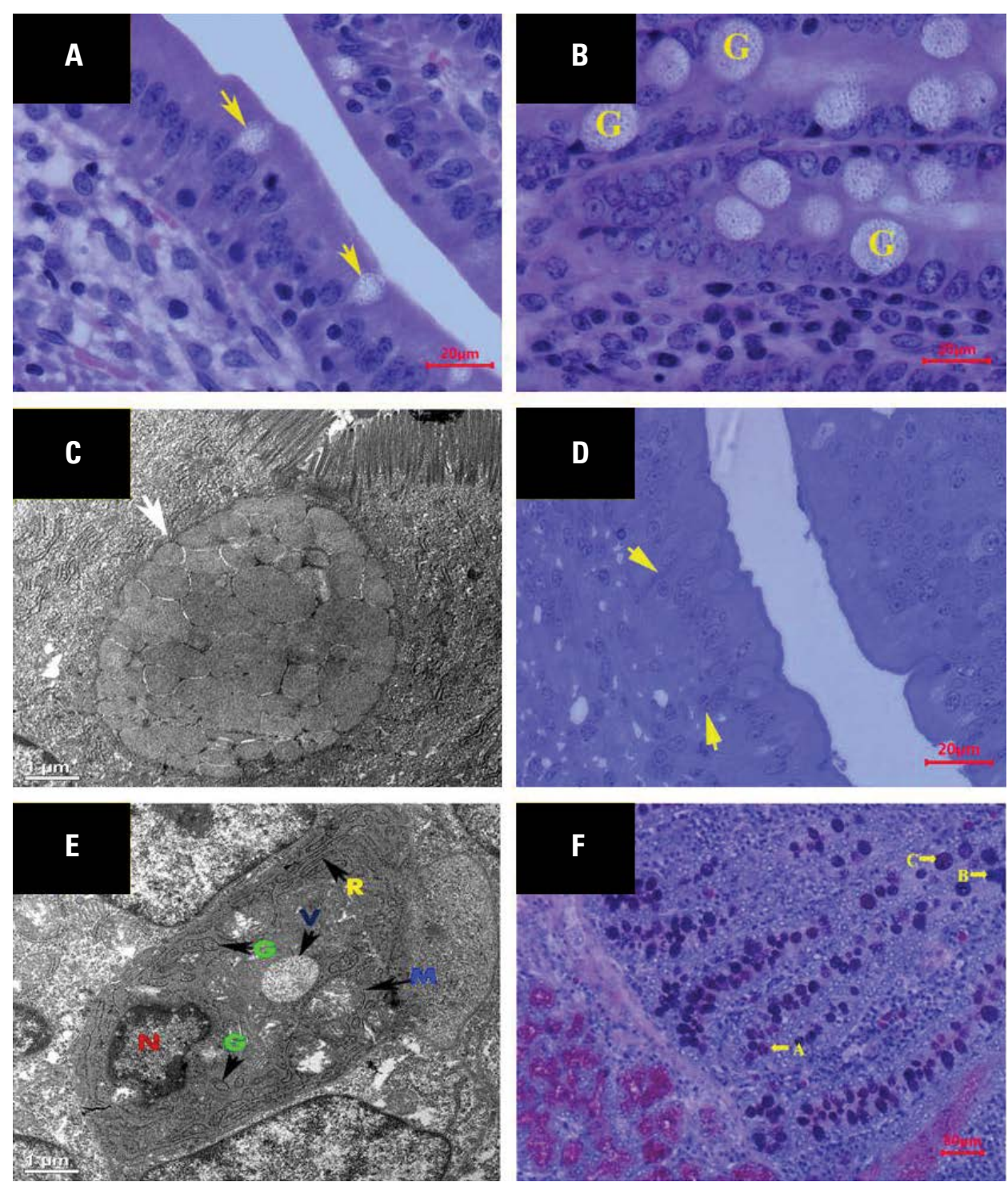

Figure 2. Goblet cells. A, B. Photomicrographs showing goblet cells in villus epithelium (arrow) and crypt epithelium (G) in the duodenum of 60 days old treated piglet $(\mathrm{H} \& \mathrm{E}, \times 400)$; C. Transmission electron microscopy (TEM) micrograph of goblet cell showing abundant mucous laden granules in the ileum of 60 days old treated piglet; D. Photomicrograph of the semi-thin section showing goblet cells with distended apical portion and stem-like basal portion (arrow) in the jejunum of 60 days old treated piglet (toluidine-blue, $\times 400$ ); E. TEM micrograph of goblet cell showing mitochondria (M), Golgi bodies (G), rough endoplasmic reticulum (R), nucleus (N) and secretory vesicles (V) in the ileum of 60 days old treated piglet; F. Photomicrograph showing neutral (A), acidic (B) and mixed (C) mucins goblet cells in the jejunum of 60 days old treated piglet (AB-PAS, $\times 100$ ).

irregular microvilli (Fig. 4A) and basolateral indentations or pockets for transportation of antigens and microbes across intestinal epithelium (Fig. 4B). The cytoplasm of villus $\mathrm{M}$-cells was less electron-dense (Fig. 4C) that contained few secretory granules and lysosomes, rich in mitochondria and numerous small vesicles (Fig. 4D).

Under TEM, the mucosal epithelium of the small intestine showed tuft cell in between the enterocytes (Fig. 5). These pear-shaped cells had a broad base, narrow apex, and a "tuft" of microvilli projecting into the lumen.
In this study, these cells were encountered more in the duodenum than jejunum and ileum. The frequent occurrences of tuft cells were noted in the treatment group of piglets in comparison to the control group of animals.

The IELs were unevenly distributed at apical, nuclear and basal positions in the lining mucosa of the small intestine (Fig. 6A) in both the groups. In most of the segments of the intestine, the number of IEL population was significantly higher in the treatment group of piglets both in the villus tip and base (Table 3 ). The treatment group of piglets had a significantly 
Table 1. Numbers of Alcian blue-periodic acid Schiff (AB-PAS) positive goblet cells in the small intestine of piglets fed with probiotic and zinc

\begin{tabular}{|c|c|c|c|c|c|c|c|c|c|}
\hline \multirow[t]{3}{*}{ Parameter } & \multirow{3}{*}{$\begin{array}{l}\text { Intestinal } \\
\text { segment }\end{array}$} & \multirow{2}{*}{\multicolumn{2}{|c|}{$\begin{array}{c}\text { Pre-weaning } \\
\text { Day } 20\end{array}$}} & \multicolumn{4}{|c|}{ Post-weaning } & \multicolumn{2}{|c|}{ P-value } \\
\hline & & & & \multicolumn{2}{|c|}{ Day 30} & \multicolumn{2}{|c|}{ Day 60} & & \\
\hline & & Control & Treatment & Control & Treatment & Control & Treatment & Control & Treatment \\
\hline \multirow{3}{*}{$\begin{array}{l}\text { Villus neutral } \\
\text { per } 200 \mu \mathrm{m}\end{array}$} & Duodenum & $0.33 \pm 0.11^{\text {ap }}$ & $0.87 \pm 0.13^{q}$ & $0.73 \pm 0.19^{\mathrm{ab}}$ & $1.03 \pm 0.29$ & $0.87 \pm 0.21^{b}$ & $1.20 \pm 0.19$ & 0.08 & 0.55 \\
\hline & Jejunum & $0.57 \pm 0.16^{\mathrm{a}}$ & $0.97 \pm 0.15^{d}$ & $0.93 \pm 0.16^{\mathrm{ab}}$ & $1.33 \pm 0.13^{\mathrm{de}}$ & $1.10 \pm 0.15^{b}$ & $1.60 \pm 0.28^{\mathrm{e}}$ & 0.05 & 0.08 \\
\hline & lleum & $0.67 \pm 0.12^{\mathrm{a}}$ & $1.07 \pm 0.18^{d}$ & $1.03 \pm 0.20^{\mathrm{ab}}$ & $1.50 \pm 0.18^{\mathrm{de}}$ & $1.23 \pm 0.23^{\mathrm{br}}$ & $1.93 \pm 0.26^{\mathrm{es}}$ & 0.10 & 0.02 \\
\hline \multirow{3}{*}{$\begin{array}{l}\text { Villus acidic } \\
\text { per } 200 \mu \mathrm{m}\end{array}$} & Duodenum & $0.23 \pm 0.09^{a r}$ & $0.73 \pm 0.19^{s}$ & $0.70 \pm 0.19^{b}$ & $0.93 \pm 0.21$ & $0.80 \pm 0.17^{\mathrm{b}}$ & $1.07 \pm 0.25$ & 0.03 & 0.55 \\
\hline & Jejunum & $0.47 \pm 0.12$ & $0.87 \pm 0.18$ & $0.80 \pm 0.24$ & $1.20 \pm 0.22$ & $0.93 \pm 0.21$ & $1.50 \pm 0.26$ & 0.22 & 0.14 \\
\hline & lleum & $0.47 \pm 0.12^{\mathrm{ar}}$ & $0.87 \pm 0.15^{\mathrm{s}}$ & $0.93 \pm 0.17^{\mathrm{ab}}$ & $1.43 \pm 0.29$ & $1.10 \pm 0.27^{\mathrm{b}}$ & $1.80 \pm 0.46$ & 0.07 & 0.13 \\
\hline \multirow{3}{*}{$\begin{array}{l}\text { Villus mixed } \\
\text { per } 200 \mu \mathrm{m}\end{array}$} & Duodenum & $2.83 \pm 0.29$ & $2.90 \pm 0.28^{D}$ & $2.90 \pm 0.27$ & $3.03 \pm 0.34^{\mathrm{D}}$ & $3.40 \pm 0.43^{p}$ & $4.97 \pm 0.38^{\mathrm{Eq}}$ & 0.44 & 0.001 \\
\hline & Jejunum & $2.97 \pm 0.36$ & $3.57 \pm 0.34^{D}$ & $3.57 \pm 0.42$ & $4.77 \pm 0.30^{\mathrm{Es}}$ & $3.73 \pm 0.34^{p}$ & $5.17 \pm 0.31^{\mathrm{Eq}}$ & 0.32 & 0.002 \\
\hline & lleum & $3.0 \pm 0.24$ & $3.70 \pm 0.32^{D}$ & $3.77 \pm 0.42^{r}$ & $5.03 \pm 0.25^{\mathrm{Es}}$ & $3.93 \pm 0.34^{p}$ & $5.57 \pm 0.27^{\mathrm{Eq}}$ & 0.12 & 0.001 \\
\hline \multirow{3}{*}{$\begin{array}{l}\text { Villus total } \\
\text { per } 200 \mu \mathrm{m}\end{array}$} & Duodenum & $3.40 \pm 0.2 \mathrm{~g}^{\mathrm{Ar}}$ & $4.50 \pm 0.37^{\mathrm{Ds}}$ & $4.33 \pm 0.35^{\mathrm{AB}}$ & $5.0 \pm 0.36^{D}$ & $5.07 \pm 0.45^{8 p}$ & $7.23 \pm 0.49^{\mathrm{Eq}}$ & 0.01 & 0.001 \\
\hline & Jejunum & $4.0 \pm 0.45^{\mathrm{ar}}$ & $5.40 \pm 0.41^{\mathrm{Ds}}$ & $5.30 \pm 0.47^{\text {bp }}$ & $7.30 \pm 0.36^{\mathrm{Eq}}$ & $5.77 \pm 0.3 g^{\text {bp }}$ & $8.27 \pm 0.47^{\mathrm{Eq}}$ & 0.02 & 0.001 \\
\hline & lleum & $4.13 \pm 0.32^{p}$ & $5.63 \pm 0.34^{\mathrm{Dq}}$ & $5.73 \pm 0.54^{p}$ & $7.97 \pm 0.39^{\text {Еq }}$ & $6.27 \pm 0.46^{p}$ & $9.30 \pm 0.53^{F q}$ & 0.003 & 0.001 \\
\hline \multirow{3}{*}{$\begin{array}{l}\text { Crypt neutral } \\
\text { per } 200 \mu \mathrm{m}\end{array}$} & Duodenum & $0.50 \pm 0.15^{a}$ & $0.93 \pm 0.17^{D}$ & $0.83 \pm 0.19^{\mathrm{ab}}$ & $1.23 \pm 0.22^{D}$ & $1.30 \pm 0.25^{b}$ & $2.0 \pm 0.32^{E}$ & 0.02 & 0.009 \\
\hline & Jejunum & $0.77 \pm 0.17^{\text {ap }}$ & $1.43 \pm 0.18^{d q}$ & $1.13 \pm 0.21^{\mathrm{abr}}$ & $1.77 \pm 0.15^{\text {des }}$ & $1.60 \pm 0.28^{b}$ & $2.13 \pm 0.32^{\mathrm{e}}$ & 0.04 & 0.11 \\
\hline & lleum & $0.80 \pm 0.24 r$ & $1.47 \pm 0.23^{\mathrm{ds}}$ & $1.23 \pm 0.20$ & $1.83 \pm 0.27^{\mathrm{de}}$ & $1.40 \pm 0.24$ & $2.33 \pm 0.29^{e s}$ & 0.16 & 0.07 \\
\hline \multirow{3}{*}{$\begin{array}{l}\text { Crypt acidic } \\
\text { per } 200 \mu \mathrm{m}\end{array}$} & Duodenum & $0.20 \pm 0.12^{A p}$ & $0.67 \pm 0.12^{q}$ & $0.63 \pm 0.14^{\mathrm{B}}$ & $0.87 \pm 0.15$ & $0.77 \pm 0.12^{B}$ & $0.93 \pm 0.18$ & 0.01 & 0.44 \\
\hline & Jejunum & $0.30 \pm 0.09^{A p}$ & $0.77 \pm 0.15^{d q}$ & $0.73 \pm 0.14^{B}$ & $1.07 \pm 0.17^{\mathrm{de}}$ & $0.87 \pm 0.12^{\mathrm{Br}}$ & $1.47 \pm 0.19^{\text {es }}$ & 0.003 & 0.02 \\
\hline & lleum & $0.47 \pm 0.10^{\mathrm{ar}}$ & $0.83 \pm 0.16^{\mathrm{Ds}}$ & $0.83 \pm 0.20^{\mathrm{ab}}$ & $1.37 \pm 0.1 g^{E}$ & $1.0 \pm 0.21^{\mathrm{br}}$ & $1.63 \pm 0.19^{\mathrm{Es}}$ & 0.10 & 0.006 \\
\hline \multirow{3}{*}{$\begin{array}{l}\text { Crypt mixed } \\
\text { per } 200 \mu \mathrm{m}\end{array}$} & Duodenum & $4.30 \pm 0.34$ & $4.63 \pm 0.37^{d}$ & $4.40 \pm 0.28$ & $4.77 \pm 0.42^{\mathrm{de}}$ & $4.73 \pm 0.36^{r}$ & $5.90 \pm 0.42^{\mathrm{es}}$ & 0.62 & 0.06 \\
\hline & Jejunum & $4.43 \pm 0.37$ & $4.73 \pm 0.34^{d}$ & $4.50 \pm 0.48$ & $5.40 \pm 0.39^{\mathrm{de}}$ & $4.83 \pm 0.40^{r}$ & $6.0 \pm 0.42^{\mathrm{es}}$ & 0.77 & 0.07 \\
\hline & lleum & $4.73 \pm 0.46$ & $5.0 \pm 0.38$ & $4.80 \pm 0.32$ & $5.60 \pm 0.52$ & $5.10 \pm 0.44$ & $6.20 \pm 0.38$ & 0.80 & 0.15 \\
\hline \multirow{3}{*}{$\begin{array}{l}\text { Crypt total } \\
\text { per } 200 \mu \mathrm{m}\end{array}$} & Duodenum & $5.0 \pm 0.37^{\mathrm{Ar}}$ & $6.23 \pm 0.44^{D s}$ & $5.87 \pm 0.38^{\mathrm{AB}}$ & $6.87 \pm 0.46^{D}$ & $6.80 \pm 0.43^{B p}$ & $8.83 \pm 0.60^{\mathrm{Eq}}$ & 0.01 & 0.001 \\
\hline & Jejunum & $5.50 \pm 0.32^{\mathrm{ap}}$ & $6.93 \pm 0.41^{\mathrm{Dq}}$ & $6.37 \pm 0.57^{\mathrm{abr}}$ & $8.23 \pm 0.47^{\text {DEs }}$ & $7.30 \pm 0.57^{\text {bp }}$ & $9.60 \pm 0.59^{\text {Eq }}$ & 0.04 & 0.001 \\
\hline & lleum & $6.0 \pm 0.54$ & $7.30 \pm 0.51^{\mathrm{D}}$ & $6.87 \pm 0.46^{r}$ & $8.80 \pm 0.60^{\mathrm{DES}}$ & $7.50 \pm 0.56^{p}$ & $10.17 \pm 0.49^{\text {Eq }}$ & 0.13 & 0.001 \\
\hline
\end{tabular}

Data are presented as goblet cells/200 $\mu \mathrm{m}$ (mean \pm scanning electron microscopy) in different age-groups.

$\mathrm{A}, \mathrm{B}$ Means with different superscripts between control groups significantly differ $(\mathrm{p}<0.01)$;

$D, E, F$ Means with different superscripts between treatment groups significantly differ $(p<0.01)$;

$a, b$ Means with different superscripts between control groups significantly differ $(p<0.05)$;

$\mathrm{d}, e$ Means with different superscripts between treatment groups significantly differ $(\mathrm{p}<0.05)$;

p.qMeans with different superscripts within groups significantly differ $(p<0.01)$;

${ }^{r, s}$ Means with different superscripts within groups significantly differ $(p<0.05)$.

higher number of basally located IEL (Fig. 6B) followed by nuclear level both in villus tip and base at different age-groups.

At the bases of the crypts, TEM analysis revealed the presence of crypt base columnar (CBC) stem cells, goblet cells, enteroendocrine cells and absorptive enterocytes in all segments of the small intestine (Fig. 7). The stem cells were irregularly shaped, small, columnar cells with basally located nuclei and scarce cytoplasm. They were found in between the goblet cells, enterocytes or enteroendocrine cells in piglets. The CBC stem cells could be differentiated from the mature absorptive enterocytes with their irregular columnar cells containing uneven elongated nuclei in between the goblet cells (Fig. 7).

\section{DISCUSSION}

The results of the current study revealed that treatment with probiotic and zinc significantly increased $(p<0.05)$ the length of microvilli in jejunum and ileum at day 30 and day 60 in post-weaned piglets. This might be showing the greater surface area, which could attribute more absorption of nutrients by the small intestine in piglets fed with probiotic and zinc. The comparison of the present finding could not be discussed with the available literature due to the 

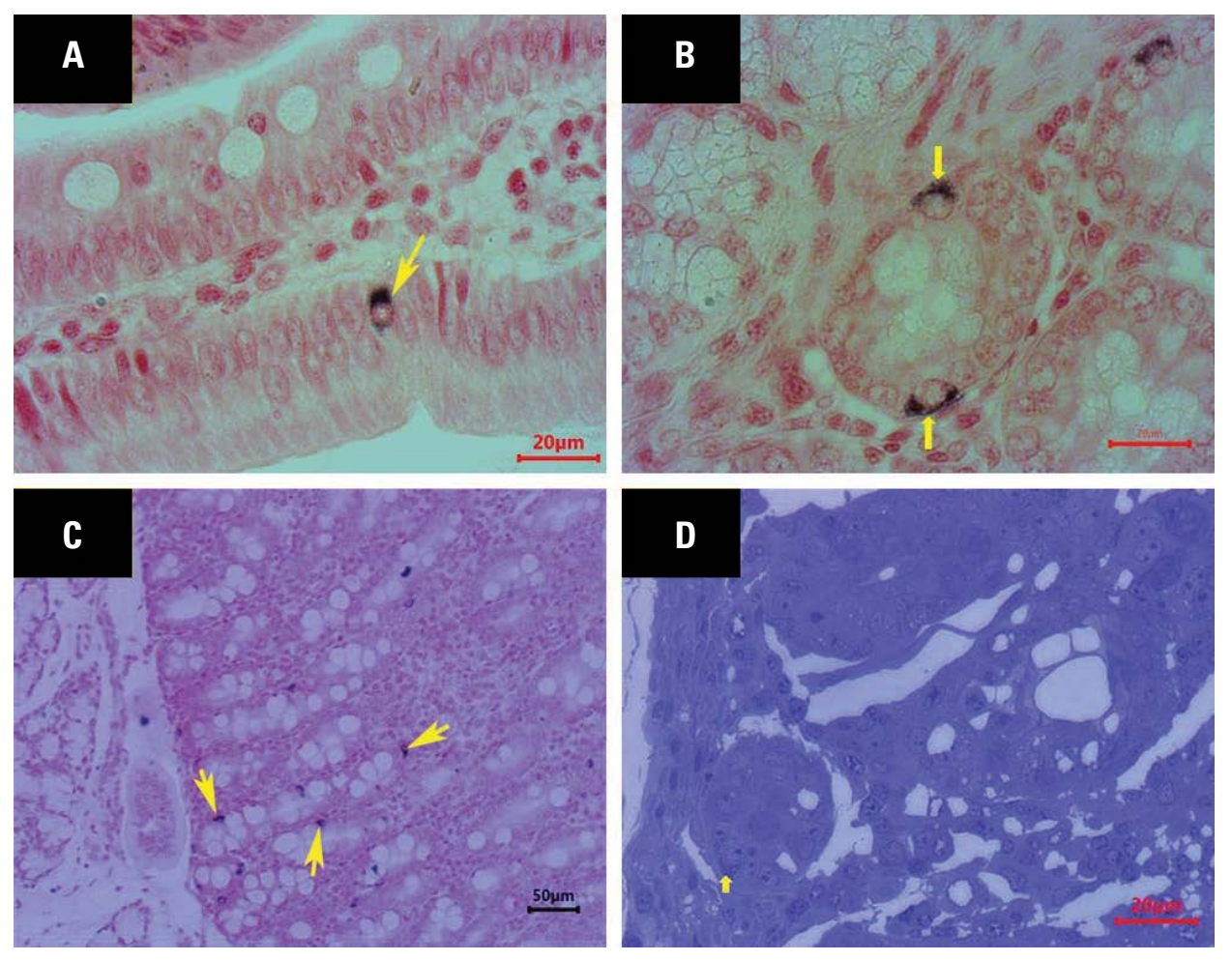

Figure 3. Photomicrographs of argentaffin cells. A, B. Argentaffin cells (arrow) in the villus and crypt epithelium of duodenum in 20 days old treated piglet $(\mathrm{H} \& \mathrm{E}, \times 100)$; C. Abundant numbers of argentaffin cells (arrow) in the crypts of the duodenum of 30 days old treated piglet $(\mathrm{H} \& \mathrm{E}$, $\times 100$ ); D. Semi-thin section showing argentaffin cells (arrow) in the crypts of jejunum in 30 days old treated piglet (toluidine blue, $\times 400$ ).

Table 2. Numbers of argentaffin cells in the small intestine of piglets fed with probiotic and zinc

\begin{tabular}{|c|c|c|c|c|c|c|c|c|c|}
\hline \multirow[t]{3}{*}{ Parameter } & \multirow{3}{*}{$\begin{array}{l}\text { Intestinal } \\
\text { segment }\end{array}$} & \multirow{2}{*}{\multicolumn{2}{|c|}{$\begin{array}{c}\text { Pre-weaning } \\
\text { Day } 20\end{array}$}} & \multicolumn{4}{|c|}{ Post-weaning } & \multirow{2}{*}{\multicolumn{2}{|c|}{ P-value }} \\
\hline & & & & \multicolumn{2}{|c|}{ Day 30} & \multicolumn{2}{|c|}{ Day 60} & & \\
\hline & & Control & Treatment & Control & Treatment & Control & Treatment & Control & Treatment \\
\hline \multirow{3}{*}{$\begin{array}{l}\text { Villus } \\
\text { argentaffin } \\
\text { cell }\end{array}$} & Duodenum & $0.40 \pm 0.10$ & $0.47 \pm 0.10^{A}$ & $0.43 \pm 0.09$ & $0.60 \pm 0.10^{A}$ & $0.53 \pm 0.13^{r}$ & $1.0 \pm 0.16^{\mathrm{Bs}}$ & 0.68 & 0.009 \\
\hline & Jejunum & $0.50 \pm 0.13$ & $0.77 \pm 0.18$ & $0.50 \pm 0.12$ & $0.67 \pm 0.11$ & $0.53 \pm 0.10$ & $0.60 \pm 0.14$ & 0.97 & 0.72 \\
\hline & lleum & $0.33 \pm 0.13$ & $0.43 \pm 0.09$ & $0.50 \pm 0.09$ & $0.63 \pm 0.11$ & $0.57 \pm 0.11$ & $0.70 \pm 0.12$ & 0.33 & 0.20 \\
\hline \multirow{3}{*}{$\begin{array}{l}\text { Crypt } \\
\text { argentaffin } \\
\text { cell }\end{array}$} & Duodenum & $1.27 \pm 0.10$ & $1.40 \pm 0.11^{\mathrm{A}}$ & $1.33 \pm 0.10$ & $1.53 \pm 0.09^{A}$ & $1.43 \pm 0.11^{p}$ & $2.03 \pm 0.16^{B q}$ & 0.52 & 0.002 \\
\hline & Jejunum & $1.40 \pm 0.13$ & $1.53 \pm 0.14$ & $1.40 \pm 0.12$ & $1.60 \pm 0.17$ & $1.43 \pm 0.16$ & $1.67 \pm 0.15$ & 0.98 & 0.83 \\
\hline & lleum & $0.80 \pm 0.12$ & $1.07 \pm 0.13$ & $0.90 \pm 0.12$ & $1.17 \pm 0.14$ & $1.0 \pm 0.15$ & $1.27 \pm 0.14$ & 0.57 & 0.57 \\
\hline
\end{tabular}

Data are presented as the argentaffin cells $/ 0.24 \mathrm{~mm}^{2}$ area (mean \pm scanning electron microscopy) in different age-groups.

$A, B$ Means with different superscripts between treatment groups significantly differ $(p<0.01)$;

p.qMeans with different superscripts within groups significantly differ $(p<0.01)$;

${ }_{\mathrm{r}, \mathrm{s}}$ Means with different superscripts within groups significantly differ $(\mathrm{p}<0.05)$.

dearth of information in this regard. In the current study, the electron microscopy studies confirmed the high activation of enterocytes after dietary inclusion of probiotic and zinc in pre- and post-weaned piglets as compared to the control group. This finding might indicate that probiotic and zinc interacted and activated the intestinal epithelial cells (IECs), which could improve their functions and activate the immune cells present in the small intestine. This fact is in line with previous reports where probiotic strains interact and activate the intestinal epithelial cells [21, 32].

Goblet cells containing different mucins acted as an innate defence mechanism, acting as a diffusion barrier and providing a microecological barrier in the gut [33]. Acid glycoconjugates especially helped the intestinal mucosa to counteract microorganisms and resisted bacterial enzymes [16]. The secretion of mucous from goblet cells was also affected by wean- 

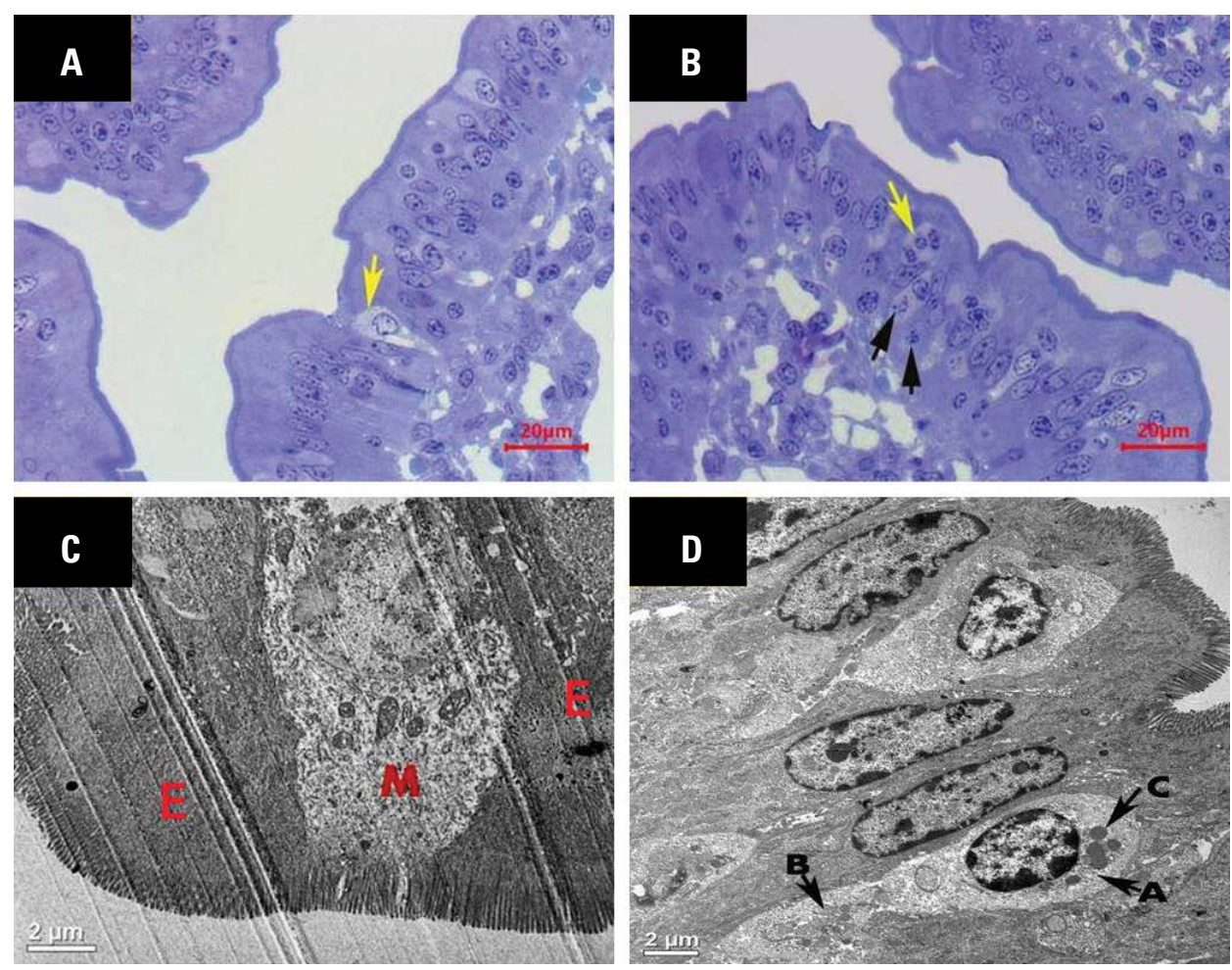

Figure 4. Photomicrographs of M-cells. A. Semi-thin section showing M-cell with irregular microvilli (arrow) in 60 days old treated piglet (toluidine-blue, $\times 400$ ); B. Semi-thin section showing M-cell with basolateral pockets (yellow arrow) and trapped antigens (black arrow) in 30 days old treated piglet (toluidine-blue, $\times 400$ ); C. Transmission electron microscopy (TEM) micrograph showing less electron-dense M-cell (M) adjacent to enterocytes (E) in 30 days old treated piglet; D. TEM micrograph of M-cell containing small vesicles (A), mitochondria (B) and lysosomes $(\mathrm{C})$ in 30 days old treated piglet.

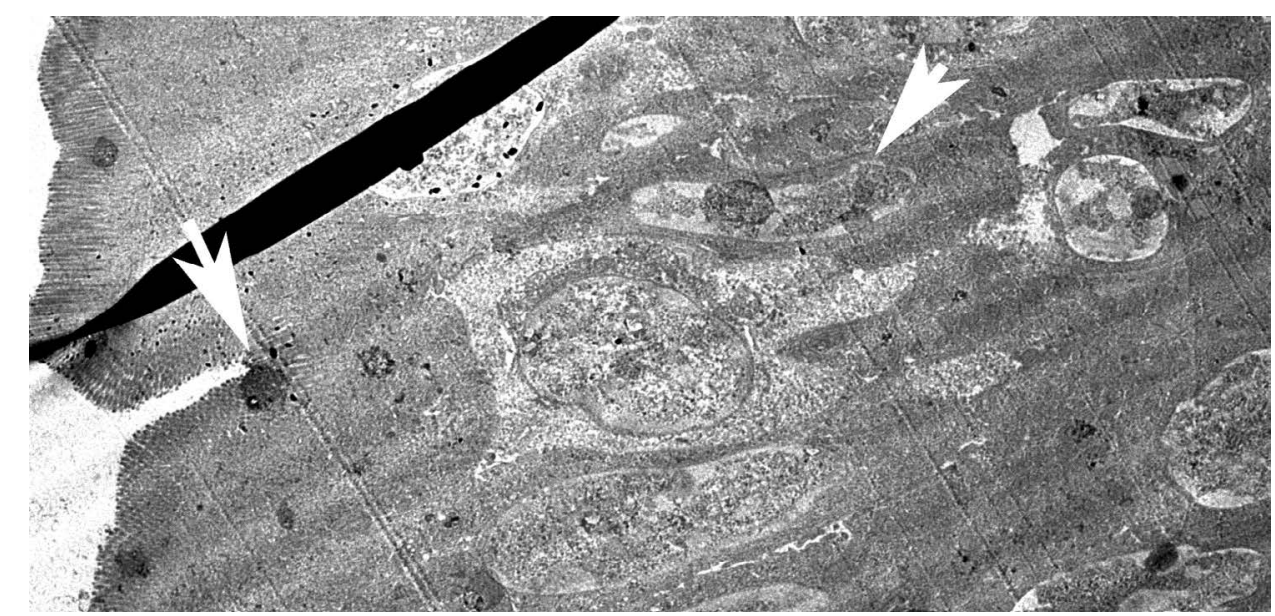

Figure 5. Transmission electron microscopy micrograph showing pear-shaped, wide base and narrow apex tuft cell containing tuft (arrow) in the jejunum of 30 days old treated piglet.

ing and age of the animals [11], the composition of intestinal microbiota [12], and dietary treatment [27]. In our study, the goblet cells were observed both in the villi and crypts of the small intestine as reported by Liu et al. [34] in piglet. These cells appeared as an accumulation of mucous granules with a stem-like basal portion. Similar type of observation was also recorded by Hodges and Dartt [28] in the conjunctiva of eye. In the current study, the number of goblet cells with different mucins increased significantly in most of the segments of the small intestine at different age-groups of treated piglets as compared to the control 
Table 3. Numbers of intraepithelial lymphocytes (IEL) in the small intestine in piglets fed with probiotic and zinc

\begin{tabular}{|c|c|c|c|c|c|c|c|c|c|}
\hline \multirow[t]{3}{*}{ Parameter } & \multirow{3}{*}{$\begin{array}{l}\text { Intestinal } \\
\text { segment }\end{array}$} & \multirow{2}{*}{\multicolumn{2}{|c|}{$\begin{array}{c}\text { Pre-weaning } \\
\text { Day } 20 \\
\end{array}$}} & \multicolumn{4}{|c|}{ Post-weaning } & \multicolumn{2}{|c|}{ P-value } \\
\hline & & & & \multicolumn{2}{|c|}{ Day 30} & \multicolumn{2}{|c|}{ Day 60} & \multirow[b]{2}{*}{ Control } & \multirow[b]{2}{*}{ Treatment } \\
\hline & & Control & Treatment & Control & Treatment & Control & Treatment & & \\
\hline \multirow{3}{*}{$\begin{array}{l}\text { Apical IEL } \\
\text { villus tip per } \\
100 \mu \mathrm{m}\end{array}$} & Duodenum & $1.57 \pm 0.21$ & $1.63 \pm 0.21^{D}$ & $1.90 \pm 0.26^{p}$ & $3.17 \pm 0.25^{\text {Eq }}$ & $2.13 \pm 0.26$ & $2.30 \pm 0.19^{F}$ & 0.26 & 0.001 \\
\hline & Jejunum & $1.47 \pm 0.29^{\mathrm{a}}$ & $1.27 \pm 0.24^{\text {de }}$ & $0.87 \pm 0.17^{\mathrm{abp}}$ & $1.60 \pm 0.19^{d q}$ & $0.73 \pm 0.16^{b}$ & $0.90 \pm 0.12^{\mathrm{e}}$ & 0.04 & 0.04 \\
\hline & lleum & $0.97 \pm 0.19^{\mathrm{a}}$ & $0.87 \pm 0.17^{d}$ & $0.60 \pm 0.13^{\mathrm{ab}}$ & $0.73 \pm 0.14^{\mathrm{de}}$ & $0.47 \pm 0.12^{b}$ & $0.37 \pm 0.11^{\mathrm{e}}$ & 05 & 0.04 \\
\hline \multirow{3}{*}{$\begin{array}{l}\text { Nuclear IEL } \\
\text { villus tip per } \\
100 \mu \mathrm{m}\end{array}$} & Duodenum & $1.27 \pm 0.16^{A}$ & $1.37 \pm 0.17^{d}$ & $2.30 \pm 0.26^{B}$ & $2.07 \pm 0.17^{\mathrm{e}}$ & $2.17 \pm 0.17^{\mathrm{B}}$ & $1.90 \pm 0.20^{\mathrm{e}}$ & 0.001 & 0.02 \\
\hline & Jejunum & $0.97 \pm 0.19^{A p}$ & $3.13 \pm 0.26^{d q}$ & $2.10 \pm 0.24^{\mathrm{B}}$ & $2.07 \pm 0.30^{\mathrm{e}}$ & $1.17 \pm 0.19^{A p}$ & $2.80 \pm 0.34^{\mathrm{deq}}$ & 0.001 & 0.05 \\
\hline & lleum & $1.67 \pm 0.21^{\mathrm{ar}}$ & $1.0 \pm 0.15^{\mathrm{Ds}}$ & $1.73 \pm 0.21^{\mathrm{a}}$ & $1.80 \pm 0.20^{\mathrm{E}}$ & $1.07 \pm 0.17^{b}$ & $1.40 \pm 0.19 \mathrm{DE}$ & 0.04 & 0.01 \\
\hline \multirow{3}{*}{$\begin{array}{l}\text { Basal IEL } \\
\text { villus tip per } \\
100 \mu \mathrm{m}\end{array}$} & Duoder & $2.20 \pm 0.19^{A}$ & $2.47 \pm 0.18^{D}$ & $2.77 \pm 0.18^{\mathrm{AB}}$ & $3.30 \pm 0.32^{\mathrm{E}}$ & $3.40 \pm 0.29 \mathrm{gr}$ & $4.30 \pm 0.25^{\mathrm{Fs}}$ & 1.00 & 0.001 \\
\hline & Jejunum & $1.10 \pm 0.18^{A}$ & $1.67 \pm 0.23$ & $1.60 \pm 0.20^{\mathrm{Ar}}$ & $2.30 \pm 0.23^{s}$ & $2.73 \pm 0.29^{B p}$ & $1.73 \pm 0.19^{a}$ & 0.001 & 0.08 \\
\hline & lleum & $2.07 \pm 0.27^{\mathrm{Ar}}$ & $3.27 \pm 0.43^{\mathrm{DEs}}$ & $2.50 \pm 0.19^{A}$ & $2.63 \pm 0.18^{D}$ & $3.77 \pm 0.24^{B}$ & $3.93 \pm 0.21^{E}$ & 0.001 & 0.01 \\
\hline \multirow{3}{*}{$\begin{array}{l}\text { Total IEL } \\
\text { villus tip per } \\
100 \mu \mathrm{m}\end{array}$} & Duodenum & $5.03 \pm 0.32^{A}$ & $5.47 \pm 0.29^{D}$ & $6.97 \pm 0.40^{\mathrm{Bp}}$ & $8.53 \pm 0.33^{\mathrm{Eq}}$ & $7.70 \pm 0.33^{B}$ & $8.50 \pm 0.31^{\mathrm{E}}$ & 0.001 & 0.001 \\
\hline & Jejunum & $3.53 \pm 0.23^{a p}$ & $6.07 \pm 0.40^{\natural}$ & $4.57 \pm 0.35^{\mathrm{bp}}$ & $5.97 \pm 0.33^{q}$ & $4.63 \pm 0.36^{b}$ & $5.43 \pm 0.27$ & 0.03 & 0.36 \\
\hline & lleum & $4.70 \pm 0.25$ & $5.13 \pm 0.49$ & $4.83 \pm 0.32$ & $5.23 \pm 0.28$ & $5.30 \pm 0.34$ & $5.70 \pm 0.25$ & 0.35 & 040 \\
\hline \multirow{3}{*}{$\begin{array}{l}\text { Apical IEL } \\
\text { villus base } \\
\text { per } 100 \mu \mathrm{m}\end{array}$} & Duodenum & $1.63 \pm 0.15$ & $1.70 \pm 0.15^{d}$ & $2.10 \pm 0.28$ & $1.27 \pm 0.28^{\text {des }}$ & $2.0 \pm 0.21^{p}$ & $1.07 \pm 0.17^{\mathrm{eq}}$ & 0.30 & 0.09 \\
\hline & Jejunum & $1.10 \pm 0.19$ & $0.97 \pm 0.20^{d}$ & $0.87 \pm 0.16^{p}$ & $1.73 \pm 0.20^{\mathrm{eq}}$ & $0.73 \pm 0.12$ & $1.13 \pm 0.17^{d}$ & 0.25 & 0.014 \\
\hline & lleum & $1.13 \pm 0.16^{A}$ & $0.90 \pm 0.17^{\circ}$ & $1.27 \pm 0.14^{A}$ & $1.27 \pm 0.14^{D}$ & $0.50 \pm 0.10^{\mathrm{B}}$ & $0.37 \pm 0.13^{\mathrm{E}}$ & 0.001 & 0.001 \\
\hline \multirow{3}{*}{$\begin{array}{l}\text { Nuclear IEL } \\
\text { villus base } \\
\text { per } 100 \mu \mathrm{m}\end{array}$} & Duodenum & $1.37 \pm 0.18^{A}$ & $1.47 \pm 0.18^{D}$ & $2.43 \pm 0.31^{\mathrm{B}}$ & $2.60 \pm 0.22^{\mathrm{E}}$ & $2.40 \pm 0.25^{\mathrm{B}}$ & $2.73 \pm 0.19^{E}$ & 0.004 & 0.001 \\
\hline & Jejunum & $0.90 \pm 0.15^{A p}$ & $1.83 \pm 0.14^{q}$ & $1.93 \pm 0.20^{\mathrm{B}}$ & $2.0 \pm 0.19$ & $1.07 \pm 0.17^{A p}$ & $2.23 \pm 0.21^{q}$ & 0.001 & 0.30 \\
\hline & lleum & $0.93 \pm 0.14^{a}$ & $0.60 \pm 0.14^{D}$ & $1.53 \pm 0.15^{b}$ & $1.60 \pm 0.15^{\mathrm{E}}$ & $1.17 \pm 0.15^{\mathrm{abr}}$ & $0.73 \pm 0.15^{\mathrm{Ds}}$ & 0.014 & 0.001 \\
\hline \multirow{3}{*}{$\begin{array}{l}\text { Basal IEL } \\
\text { villus base } \\
\text { per } 100 \mu \mathrm{m}\end{array}$} & Duvaenumi & $1.87 \pm 0.20^{A}$ & $2.10 \pm 0.18^{D}$ & $2.80 \pm 0.23^{B p}$ & $4.60 \pm 0.34^{\mathrm{Eq}}$ & $3.70 \pm 0.24^{C}$ & $4.40 \pm 0.27^{\mathrm{E}}$ & 0.001 & 0.001 \\
\hline & Jejunum & $1.47 \pm 0.17^{A}$ & $1.97 \pm 0.26$ & $2.10 \pm 0.22^{\mathrm{A}}$ & $2.20 \pm 0.26$ & $3.03 \pm 0.30^{B p}$ & $2.03 \pm 0.20^{\natural}$ & 0.001 & 0.78 \\
\hline & lleum & $1.77 \pm 0.20^{\mathrm{ar}}$ & $2.60 \pm 0.355^{\mathrm{s}}$ & $2.50 \pm 0.24^{b}$ & $2.63 \pm 0.23^{D}$ & $2.03 \pm 0.24^{\mathrm{abp}}$ & $4.10 \pm 0.22^{\mathrm{Eq}}$ & 0.07 & 0.001 \\
\hline \multirow{3}{*}{$\begin{array}{l}\text { Total IEL } \\
\text { villus base } \\
\text { per } 100 \mu \mathrm{m}\end{array}$} & Duodenum & $4.87 \pm 0.41^{\mathrm{A}}$ & $5.27 \pm 0.37^{\circ}$ & $7.33 \pm 0.62^{\mathrm{B}}$ & $8.47 \pm 0.35^{\mathrm{E}}$ & $8.10 \pm 0.31^{B}$ & $8.20 \pm 0.34^{E}$ & 0.001 & 0.001 \\
\hline & Jejunum & $3.43 \pm 0.28^{A p}$ & $4.77 \pm 0.38^{q}$ & $4.90 \pm 0.33^{\mathrm{B}}$ & $5.83 \pm 0.35$ & $4.83 \pm 0.35^{\mathrm{B}}$ & $5.40 \pm 0.39$ & 0.002 & 0.13 \\
\hline & lleum & $3.83 \pm 0.20^{A}$ & $4.10 \pm 0.40^{\circ}$ & $5.30 \pm 0.23^{B}$ & $5.50 \pm 0.21^{\mathrm{E}}$ & $3.70 \pm 0.27^{\mathrm{Ap}}$ & $5.20 \pm 0.27^{\text {Eq }}$ & 0.001 & 0.004 \\
\hline
\end{tabular}

Data are presented as IEL/100 $\mu \mathrm{m}$ (mean \pm scanning electron microscopy) in different age-groups.

$A, B$, CMeans with different superscripts between control groups significantly differ $(p<0.01)$;

$D, E, F$ Means with different superscripts between treatment groups significantly differ $(p<0.01)$;

$a, b$ Means with different superscripts between control groups significantly differ $(p<0.05)$;

${ }^{\mathrm{d}, e}$ Means with different superscripts between treatment groups significantly differ $(p<0.05)$;

$p, q$ Means with different superscripts within groups significantly differ $(p<0.01)$

${ }^{\mathrm{r}, \mathrm{s}}$ Means with different superscripts within groups significantly differ $(\mathrm{p}<0.05)$.

group of animals. Many researchers studied goblet cells in piglets after feeding with probiotic and zinc $[5,7,14,17,34,42]$. Most of the results obtained from these researchers were in agreement with the present findings. In the present study, the higher number of different types of goblet cells recorded in the treatment group piglets might be concluded with the better enhancement of epithelial barrier and defence mechanism. This might result in effective immunity and digestibility in this group of piglets.

The distribution of argentaffin cells in the small intestine of control and treated piglets was studied to know the effects of probiotic and zinc on these cells. These cells were concentrated more in the jejunum, followed by duodenum and ileum. However, Sadeghi et al. [45] reported more number of argentaffin cells in the first part of the duodenum in rats. The reports of the present study were not consistent with the above findings, which might be due to variation in species. These argentaffin cells were located as a single cell within the lining epithelium of both villus and crypt in a large population on non-endocrine cells as previously reported by Sadeghi et al. [45] in rats. Under the TEM of this study, these cells had narrow apex, wide base with many small, spheroidal, electron-dense granules in the cytoplasm. The present 

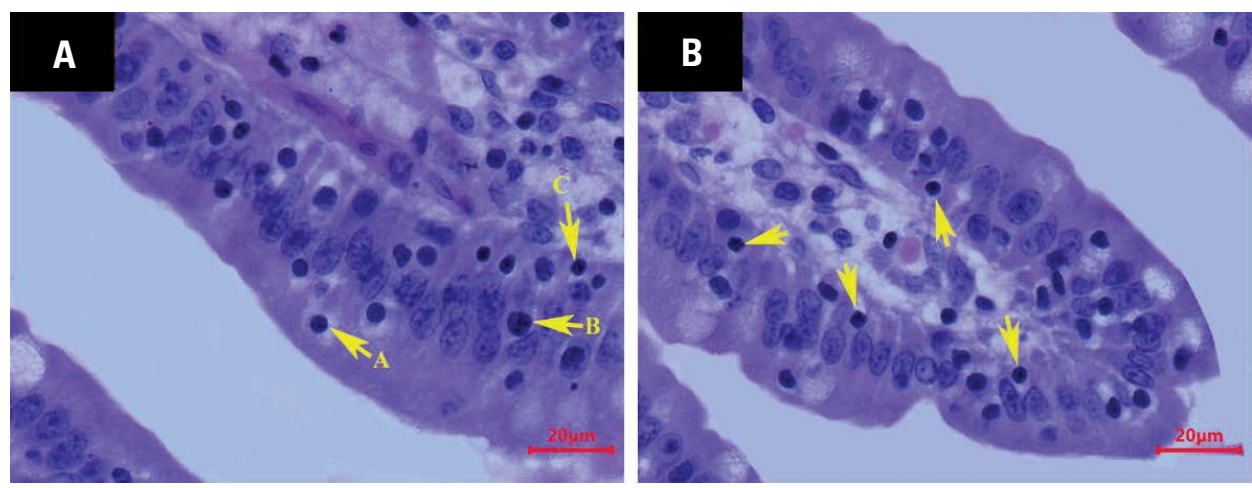

Figure 6. Photomicrographs of jejunum in 30 days old treated piglet (H\&E, $\times 400)$; $A$. Intraepithelial lymphocytes (IEL) in apical (A), nuclear (B) and basal (C) positions; B. IEL located in basal positions (arrow).

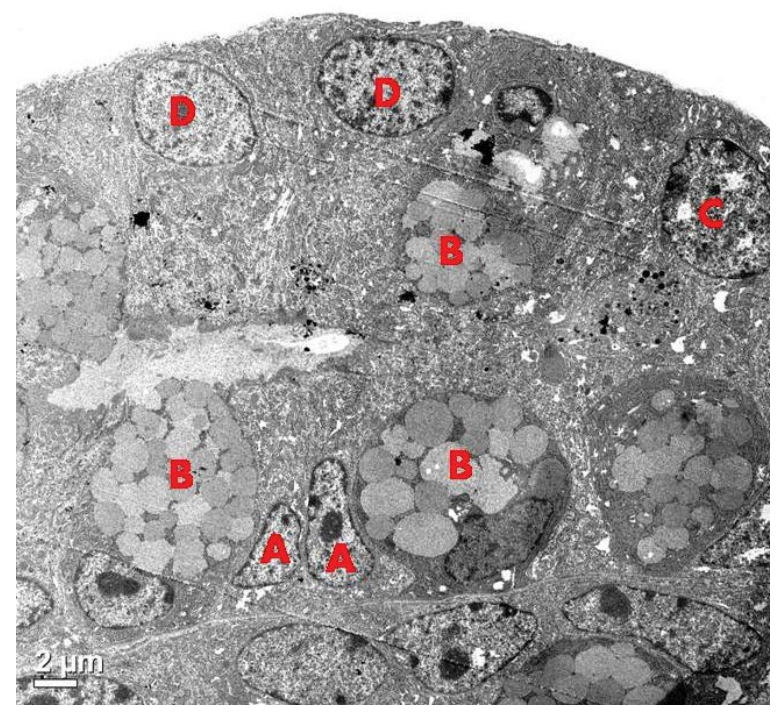

Figure 7. Transmission electron microscopy micrograph of jejunal crypt showing the presence of stem cells $(A)$, goblet cells $(B)$, argentaffin cell (C) and enterocytes (D) in 60 days old treated piglet.

findings were similar to the findings of Gonzalez et al. [23] in pigs. The mean number of argentaffin cells in the current study was significantly higher in villi $(p<0.05)$ and crypts $(p<0.01)$ of the duodenum at day 60 in the treatment group of piglets. More number of these cells revealed in the treatment group of the present study might be correlated with more production of gastrointestinal hormones for better digestion of food $[41,49]$. The increase of serotonin secretion by the argentaffin cells created a greater peristaltic movement of the small intestine resulting in effective digestion of food particles [25], which supported the current observation.

The M-cells were specialized epithelial cells of the mucosa-associated lymphoid tissue. They were mostly dispersed in the Peyer's patches of jejunum and ile- um. This finding was in consonance to the finding of Hsieh and Lo [29] in mice. In our study, the M-cells showed less developed brush border with irregular microvilli. They transport antigens from the lumen of the intestine to the dome epithelium and neutralise them with a variety of mechanisms. This finding was in agreement with the report of Gebert et al. [22] in pig. The TEM revealed less electron-dense cytoplasm containing abundant mitochondria, lysosomes and small vesicles with few secretory granules. The present findings had a close resemblance to the findings of Renfeng et al. [43] in piglets. In the present study, the differences in M-cells between control and treatment group piglets could not be made due to constraints in enough exposure availability of TEM.

In the present investigation, the mucosal epithelium of the small intestine showed a tuft cell in between the enterocytes. This pear-shaped cell had a broad base, narrow apex, and a "tuft" of microvilli projecting into the lumen as also reported by Ethan [19] in humans. In this study, these cells were encountered more in the duodenum than jejunum and ileum as revealed by Cheng et al. [10] in mouse intestine. The role of tuft cells in epithelial cell survival/self-renewal was reported by Chandrakesan et al. [9], in mucosal healing by Banerjee et al. [3] and possible contacts with nerve fibres relating to endocrine cells by Cheng et al. [10] in mouse intestine. In the present study, the counting of tuft cells in the small intestine of control and treatment group of piglets could not be made as these cells could be identified only with TEM and some special staining. However, frequent occurrences of these cells were noted in the treatment group of piglets in comparison with the control group of animals. This finding might be suggestive of better survival/self-renewal, mucosal healing and digestive 
ability in the gut of piglets fed with probiotic and zinc compared to control animals.

The intraepithelial lymphocytes were unevenly distributed in the apical, nuclear and basal positions of the lining mucosa of the small intestine in both the groups, as also opined by Deng et al. [15] in hen. In the villus tip of the treatment group of piglets, the number of these IEL was significantly increased $(p<0.01)$ at day 30 in the duodenum and, day 20 and day 30 in the jejunum. Similarly, in the villus base of the treatment group, the total IEL population was significantly higher $(p<0.01)$ at day 20 in jejunum and day 60 in the ileum. In agreement with the present result, several authors had reported an increased number of IEL after probiotic treatments in pig [46] and in chicken $[2,13,15,31]$. The slight but significant increase in the number of IEL in the treatment group of the present study could be the result of a nonspecific stimulation of the local immune system, possibly by certain antigens of probiotic bacteria. In the present study, most of the IELs were localised at the basement membrane of the epithelium, numerous at the enterocyte nuclear level and relatively few apically in the epithelium. The present findings were in support of the findings of Rieger et al. [44] and Vega-Lopez et al. [50] in the porcine small intestine. In most of the segments of intestine, the number of basally located IEL was significantly increased in the treatment group of piglets as compared to the control group of animals both in villus tip and base. The basal IEL belongs to the "conventional type", i.e., antigen-experienced cells originated from peripheral $T$ cells and homed the gut mucosa, which had immunologic memory function and mounted an adaptive response as reported by Hayday et al. [26] in human. In the present study, the treatment group of piglets had more basally located IEL that might be correlated with effective adaptive immune response in this group of piglets. A significantly higher population of IEL was also recorded at the nuclear level of villus tip and base in the jejunum of treated piglets. The more number of IEL present in the nuclear level of the epithelium was explained by Hayday et al. [26]. According to them, the IEL found at the nuclear level belongs to the "unconventional type". They had functions in between adaptive and innate responses and responsible for the protection of epithelial integrity. Further, Edelblum et al. [18] demonstrated the ability of an IEL population fitting to the "unconventional type" to contact multiple epithelial cells over a short time and thus provide a potential mechanism by which they could prevent epithelial injury and infection. The significantly higher numerical values for nuclear IEL recorded in the present study might conclude with better epithelial cell integrity against injury and infection in the piglets fed with probiotic and zinc compared to control piglets.

The TEM revealed the presence of CBC stem cells along with goblet cells, enteroendocrine cells and absorptive enterocytes, irrespective of segments of intestine and group. These stem cells were irregularly shaped, small, columnar cells with basally located nuclei and scarce cytoplasm. They were found in between the goblet cells, enterocytes or enteroendocrine cells in piglets. The present findings were in agreement with the findings of Gonzalez et al. [23] in pigs. However, Barker et al. [4] reported the presence of stem cells in between Paneth cells on the crypt base in mice. This finding slightly deviated from the present investigation might be due to the absence of Paneth cells in the crypt base of piglets. In the current study, the CBC stem cells could be differentiated from the mature absorptive enterocytes with their irregular columnar cells containing uneven elongated nuclei in between the goblet cells, as described earlier by Gonzalez et al. [23] in pigs. The alterations of CBC stem cells in the present study in between control and treatment group piglets could not be made due to a lack of sufficient view under transmission electron microscopy.

\section{CONCLUSIONS}

From the present investigation, it can be concluded that dietary supplementation of probiotic and zinc induced the length of enterocyte microvilli, increased the number of different goblet cells, argentaffin cells, tuft cells and intraepithelial lymphocytes in pre and postweaned piglets. These alterations might provide better absorption of available nutrients and stimulation of local and adaptive immune responses that resulted in effective digestibility and immunity in the treatment group of piglets as compared to the control group of animals.

Conflict of interest: None declared

\section{REFERENCES}

1. Alexander TJL. Neonatal diarrhoea in pigs. CAB International, Wallingford 1994.

2. Bai SP, Wu AM, Ding XM, et al. Effects of probiotic-supplemented diets on growth performance and intestinal immune characteristics of broiler chickens. Poult Sci. 2013; 92(3): 663-670, doi: 10.3382/ps.2012-02813, indexed in Pubmed: 23436517. 
3. Banerjee A, McKinley ET, von Moltke J, et al. Interpreting heterogeneity in intestinal tuft cell structure and function. J Clin Invest. 2018; 128(5): 1711-1719, doi: 10.1172/ JCl120330, indexed in Pubmed: 29714721.

4. Barker N, van Oudenaarden A, Clevers $H$. Identifying the stem cell of the intestinal crypt: strategies and pitfalls. Cell Stem Cell. 2012; 11(4): 452-460, doi: 10.1016/j. stem.2012.09.009, indexed in Pubmed: 23040474.

5. Baum B, Liebler-Tenorio EM, Enss ML, et al. Saccharomyces boulardii and bacillus cereus var. Toyoi influence the morphology and the mucins of the intestine of pigs. Z Gastroenterol. 2002; 40(5): 277-284, doi: 10.1055/s2002-30116, indexed in Pubmed: 12016561.

6. Blaabjerg K, Poulsen HD. The use of zinc and copper in pig production. DCA-Nationalt Center for Jordbrug of Fodevarer. 2017.

7. Bontempo V, Giancamillo ADi, Savoini G, et al. Live yeast dietary supplementation acts upon intestinal morpho-functional aspects and growth in weanling piglets. Anim Feed Sci Tech. 2006; 129(3-4): 224-236, doi: 10.1016/j.anifeedsci.2005.12.015.

8. Case CL, Carlson MS. Effect of feeding organic and inorganic sources of additional zinc on growth performance and zinc balance in nursery pigs. J Anim Sci. 2002; 80(7): 1917-1924, doi: 10.2527/2002.8071917x, indexed in Pubmed: 12162660.

9. Chandrakesan P, May R, Weygant N, et al. Intestinal tuft cells regulate the ATM mediated DNA Damage response via Dclk1 dependent mechanism for crypt restitution following radiation injury. Sci Rep. 2016; 6: 37667, doi: 10.1038/srep37667, indexed in Pubmed: 27876863.

10. Cheng X, Voss U, Ekblad E. Tuft cells: Distribution and connections with nerves and endocrine cells in mouse intestine. Exp Cell Res. 2018; 369(1): 105-111, doi: 10.1016/j. yexcr.2018.05.011, indexed in Pubmed: 29758188.

11. Choi S, Kornegay ET, Eigel W. Characterization of small intestinal mucus glycoproteins from pigs of various ages. Comp Biochem Physiol. 1991; 99(4): 677-680, doi: 10.1016/0300-9629(91)90149-7.

12. Collinder E, Cardona ME, Kozakova H, et al. Biochemical intestinal parameters in pigs reared outdoors and indoors, and in germ-free pigs. J Vet Med A Physiol Pathol Clin Med. 2002; 49(4): 203-209, doi: 10.1046/j.1439-0442.2002.00407.x, indexed in Pubmed: 12069263.

13. Dalloul RA, Lillehoj HS, Shellem TA, et al. Enhanced mucosal immunity against Eimeria acervulina in broilers fed a Lactobacillus-based probiotic. Poult Sci. 2003; 82(1): 62-66, doi: 10.1093/ps/82.1.62, indexed in Pubmed: 12580246.

14. Davis ME, Brown DC, Baker A, et al. Effect of direct-fed microbial and antibiotic supplementation on gastrointestinal microflora, mucin histochemical characterization, and immune populations of weanling pigs. Livestock Sci. 2007; 108(1-3): 249-253, doi: 10.1016/j.livsci.2007.01.063.

15. Deng W, Dong XF, Tong JM, et al. The probiotic Bacillus licheniformis ameliorates heat stress-induced impairment of egg production, gut morphology, and intestinal mucosal immunity in laying hens. Poult Sci. 2012; 91(3): 575-582, doi: 10.3382/ps.2010-01293, indexed in Pubmed: 22334732.
16. Deplancke B, Gaskins HR. Microbial modulation of innate defense: goblet cells and the intestinal mucus layer. Am J Clin Nutr. 2001; 73(6): 1131S-1141S, doi: 10.1093/ajcn/73.6.1131S, indexed in Pubmed: 11393191.

17. Di Giancamillo A, Vitari F, Savoini G, et al. Effects of orally administered probiotic Pediococcus acidilactici on the small and large intestine of weaning piglets. A qualitative and quantitative micro-anatomical study. Histol Histopathol. 2008; 23(6): 651-664, doi: 10.14670/HH-23.651, indexed in Pubmed: 18366003.

18. Edelblum KL, Shen Le, Weber CR, et al. Dynamic migration of $\gamma \delta$ intraepithelial lymphocytes requires occludin. Proc Natl Acad Sci U S A. 2012; 109(18): 7097-7102, doi: 10.1073/ pnas.1112519109, indexed in Pubmed: 22511722.

19. Ethan M. 30-anatomy and physiology of the small and large intestine. Pediatric Gastrointestinal and Liver Disease, Elsevier 2016.

20. Fuller R. Probiotics in man and animals. J Appl Microbiol. 1989; 66: 365-378, indexed in Pubmed: 2666378.

21. Galdeano CM, Perdigón G. Role of viability of probiotic strains in their persistence in the gut and in mucosal immune stimulation. J Appl Microbiol. 2004; 97(4): 673-681, doi: 10.1111/j.1365-2672.2004.02353.x, indexed in Pubmed: 15357716.

22. Gebert A, Rothkötter HJ, Pabst R. M Cells in Peyer's Patches of the Intestine. Int Rev Cytol. 1996: 91-159, doi: 10.1016/ s0074-7696(08)61346-7.

23. Gonzalez LM, Williamson I, Piedrahita JA, et al. Cell lineage identification and stem cell culture in a porcine model for the study of intestinal epithelial regeneration. PLoS One. 2013; 8(6): e66465, doi: 10.1371/journal.pone.0066465, indexed in Pubmed: 23840480.

24. Habel RE. Guide to the dissection of domestic ruminants. Edwards Brother Inc Ann Arbor, Michigan 1964.

25. Hayat MA. Immunogold-silver staining: principles, methods, and applications. CRC Press, Boca Raton, New York 1995.

26. Hayday A, Theodoridis E, Ramsburg E, et al. Intraepithelial lymphocytes: exploring the Third Way in immunology. Nat Immunol. 2001; 2(11): 997-1003, doi: 10.1038/ni1101997, indexed in Pubmed: 11685222.

27. Hedemann MS, Jensen BB, Poulsen HD. Influence of dietary zinc and copper on digestive enzyme activity and intestinal morphology in weaned pigs. J Anim Sci. 2006; 84(12): 3310-3320, doi: 10.2527/jas.2005-701, indexed in Pubmed: 17093223.

28. Hodges RR, Dartt DA. Conjunctival goblet cells. Encyclopedia of the Eye. 2010: 369-376, doi: 10.1016/b978-012-374203-2.00053-1.

29. Hsieh EH, Lo DD. Jagged1 and Notch1 help edit M cell patterning in Peyer's patch follicle epithelium. Dev Comp Immunol. 2012; 37(2): 306-312, doi: 10.1016/j. dci.2012.04.003, indexed in Pubmed: 22504165.

30. Jensen VB, Harty JT, Jones BD. Interactions of the invasive pathogens Salmonella typhimurium, Listeria monocytogenes, and Shigella flexneri with $\mathrm{M}$ cells and murine Peyer's patches. Infect Immun. 1998; 66(8): 3758-3766, doi: 10.1128/ IAI.66.8.3758-3766.1998, indexed in Pubmed: 9673259. 
31. Lee KW, Lee SH, Lillehoj HS, et al. Effects of direct-fed microbials on growth performance, gut morphometry, and immune characteristics in broiler chickens. Poult Sci. 2010; 89(2): 203-216, doi: 10.3382/ps.2009-00418, indexed in Pubmed: 20075271.

32. Lemme-Dumit JM, Polti MA, Perdigón G, et al. Probiotic bacteria cell walls stimulate the activity of the intestinal epithelial cells and macrophage functionality. Benef Microbes. 2018; 9(1): 153-164, doi: 10.3920/BM2016.0220, indexed in Pubmed: 29124968.

33. Liévin-Le Moal V, Servin AL. The front line of enteric host defense against unwelcome intrusion of harmful microorganisms: mucins, antimicrobial peptides, and microbiota. Clin Microbiol Rev. 2006; 19(2): 315-337, doi: 10.1128/CMR.19.2.315-337.2006, indexed in Pubmed: 16614252.

34. Liu P, Pieper R, Tedin L, et al. Effect of dietary zinc oxide on jejunal morphological and immunological characteristics in weaned piglets. J Anim Sci. 2014; 92(11): 5009-5018, doi: 10.2527/jas.2013-6690, indexed in Pubmed: 25253808.

35. Liu H, Zhang J, Zhang S, et al. Oral administration of Lactobacillus fermentum 15007 favors intestinal development and alters the intestinal microbiota in formula-fed piglets. J Agric Food Chem. 2014; 62(4): 860-866, doi: 10.1021/ jf403288r, indexed in Pubmed: 24404892.

36. Luna LG. Manual of histologic staining methods of Armed Forces Institute of Pathology. McGraw Hill Book Company, New York 1968.

37. Mowry RW. Observations on the use of sulphuric ether for the sulphation of hydroxyl groups in tissue sections. J Histochem Cytochem. 1956; 4: 407.

38. NRC Nutrient Requirements of Swine. In: Computer Model Program for Predicting Nutrient Requirements. National Academy of Sciences, Washington, DC, USA 1998.

39. Parsons KR, Bland AP, Hall GA. Follicle associated epithelium of the gut associated lymphoid tissue of cattle. Vet Pathol. 1991; 28(1): 22-29, doi: 10.1177/030098589102800104, indexed in Pubmed: 2017824.

40. Poulsen H. Zinc Oxide for Weanling Piglets. Acta Agric Scand Sect A Anim Sci. 2009; 45(3): 159-167, doi: 10.1080/09064709509415847.

41. Rehfeld JF. The new biology of gastrointestinal hormones. Physiol Rev. 1998; 78(4): 1087-1108, doi: 10.1152/physrev.1998.78.4.1087, indexed in Pubmed: 9790570.

42. Reiter K, Eggebrecht S, Drewes B, et al. Effects of Enterococcus faecium and Bacillus cereus var. toyoi on the morphology of the intestinal mucous membrane in piglets. Biologia. 2006; 61(6): 803-809, doi: 10.2478/ s11756-006-0161-2.

43. Renfeng Li, Xiangqin T, Songlin Q, et al. Morphological and Immunohistochemical Identification of Villous $M$ Cells in the Small Intestine of Newborn Piglets. Int J Morphol. 2015; 33(4): 1261-1268, doi: 10.4067/s071795022015000400011.

44. Rieger J, Janczyk $P$, Hünigen $H$, et al. Intraepithelial lymphocyte numbers and histomorphological parameters in the porcine gut after Enterococcus faecium NCIMB 10415 feeding in a Salmonella Typhimurium challenge. Vet Immunol Immunopathol. 2015; 164(1-2): 40-50, doi: 10.1016/j. vetimm.2014.12.013, indexed in Pubmed: 25669594.

45. Sadeghi M, Hojjati M, Sadeghi F, et al. The Distribution of Enteroendocrine Cells in Small Intestine in Rats. Int J Vet Med Res Rep. 2014: 1-7, doi: 10.5171/2014.818294.

46. Scharek L, Altherr BJ, Tölke C, et al. Influence of the probiotic Bacillus cereus var. toyoi on the intestinal immunity of piglets. Vet Immunol Immunopathol. 2007; 120(3-4): 136-147, doi: 10.1016/j.vetimm.2007.07.015, indexed in Pubmed: 17870185.

47. Singh I. A modification of the Masson-Hamperl method for staining argentaffin cells. Anat Anz. 1964; 115: 81-82, indexed in Pubmed: 14249822.

48. Skrzypek T, Valverde Piedra JL, Skrzypek H, et al. Light and scanning electron microscopy evaluation of the postnatal small intestinal mucosa development in pigs. J Physiol Pharmacol. 2005; 56 Suppl 3: 71-87, indexed in Pubmed: 16077196.

49. Solcia E, Capella C, Buffa R. The diffuse endocrine-paracrine system of the gut in health and disease: ultrastructural features. Scand J Gastroenterol. 1981; 70(Suppl.): 25-36, indexed in Pubmed: 6118945.

50. Vega-López MA, Arenas-Contreras G, Bailey M, et al. Development of intraepithelial cells in the porcine small intestine. Dev Immunol. 2001; 8(2): 147-158, doi: 10.1155/2001/25301, indexed in Pubmed: 11589310.

51. Westin R, Holmgren N, Hultgren J, et al. Post-mortem findings and piglet mortality in relation to strategic use of straw at farrowing. Prev Vet Med. 2015; 119(3-4): 141-152, doi: 10.1016/j.prevetmed.2015.02.023, indexed in Pubmed: 25792335.

52. Wilson AD, Stokes CR, Bourne FJ, et al. Effect of age on absorption and immune responses to weaning or introduction of novel dietary antigens in pigs. Res Vet Sci. 1989; 46(2): 180-186, indexed in Pubmed: 2704882. 